Article

\title{
Cruise Passengers' Intention and Sustainable Management of Cruise Destinations
}

\author{
Manuel Angel Fernández Gámez *, Jose Ramón Sánchez Serrano, Angela Callejón Gil and \\ Ana José Cisneros Ruiz
}

Department of Finance and Accounting, Campus El Ejido s/n, University of Malaga, 29071 Malaga, Spain; joseramonsanchez@uma.es (J.R.S.S.); amcallejon@uma.es (A.C.G.); ajcisneros@uma.es (A.J.C.R.)

* Correspondence: mangel@uma.es

Received: 8 March 2019; Accepted: 28 March 2019; Published: 1 April 2019

\begin{abstract}
Recent tourism studies have shown that cruise passengers' intention can be used as a tool to evaluate the sustainability of port of call destination. However, studies on this topic remain scarce and only offer an initial conceptualization of this issue. Hoping to help fill this void, the present research proposes a robust model for the analysis of the cruise passengers' intention as assessed by Partial Least Squares. Data was collected in the port of Malaga (Spain), between January and December 2018. The results showed that reputation and familiarity are the best explanatory factors of the cruise passengers' intention with a port of call destination. Also, cognitive perception and affective evaluation are the antecedents of reputation and familiarity.
\end{abstract}

Keywords: cruise tourism; intentions; reputation; familiarity; port of call destination

\section{Introduction}

Within the tourism industry, the cruise tourism sector has experienced the greatest increase worldwide. During the period 2011-2017, the increase in passengers was almost 21 percent, with a world demand in 2017 of 26.6 million cruise passengers and a global economic impact of $\$ 126$ billion [1]. This increase and its relevant economic effects have attracted the interest of cruise multinationals, tour-operators, and the ports of call, whose economies are directly and positively affected by this tourism segment [2]. Many researchers have become aware of this interest and have responded by providing a wide range of studies on the cruise industry over the last three decades [3,4].

Current research on cruises has addressed three major areas: Port of call as a tourism destination [5], passenger behaviors on the ship [6], and cruise industry impact on the environment and employment $[7,8]$. For its part, in the port of call sustainability analysis, the literature has indicated the importance of cruise passengers' intention [9]. A favorable intention to revisit the port of call destination and to recommend it through word of mouth is a way to achieve economic development. For this reason, some previous studies have tried to understand the antecedents of cruise passengers' intention [5,10-13]. However, the models used in these studies have evaluated only some of the antecedents that the general literature on tourist destinations proposes, and the cruise literature demands more robust models, capable of analyzing with greater precision the cruise passengers' intention $[5,14,15]$. Hoping to help fill this void, the present study attempts to answer the question of whether it is possible to have a robust model for the analysis of the cruise passengers' intention. For this purpose, a sample of 392 tourists who visited Malaga (Spain) on its cruise stops during 2018 has been provided. The sample completed a questionnaire that included all the variables indicated in the previous literature on tourist intention. With the information obtained, a comprehensive path model was constructed through which it was possible to verify which factors are significant to explain the intention that cruise passengers have of a port of call. After building and developing the 
conceptual model, this study shows that reputation and familiarity are the explanatory factors of the cruise passengers' intention with a port of call destination. Also, cognitive perception and affective evaluation are the antecedents of reputation and familiarity. Likewise, the proposed model provides exceptional predictive relevance for the analysis of the cruise passengers' intention.

This paper continues as follows. After a background of the literature on tourist destination and passenger intention in the cruise context, the research hypotheses are presented. Next, the survey data and results of the developed structural model are detailed. Finally, the main conclusions obtained, and the managerial implications are provided.

\section{Literature Review and Hypotheses}

The analysis of tourist intention is the issue at the center of attention in the majority of investigations on the sustainability of tourist destinations $[13,16,17]$. To analyze the behavioral intentions of cruise' passengers, a conceptual framework is necessary. This framework covers the main concepts and constructions related to the research on the antecedents and consequences of the tourist' intention. A favorable intention towards the tourist destination implies that the tourist is predisposed to revisit it and recommend it, generating business for the destination [10]. Given the importance of this intention and its economic effects, previous studies have tried to determine what their antecedents are. Among the antecedents of the tourist intention with regard to the destination, the previous literature points out the concepts of reputation, image, satisfaction, familiarity, cognitive perception and affective evaluation [16,18-21]. Figure 1 illustrates this conceptual framework showing the relationships between the antecedents of the behavioral intentions of tourist and its consequences in the tourist destination.

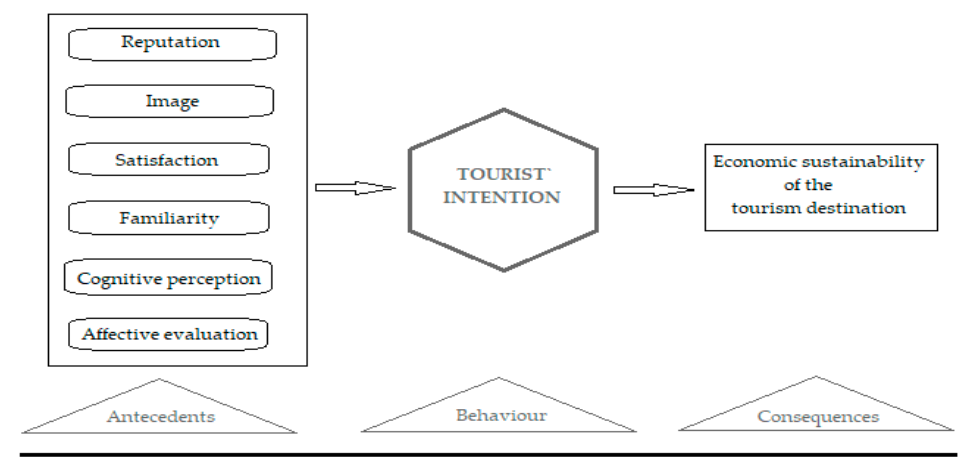

Figure 1. Conceptual framework.

Reputation plays an important role in the tourism industry. Reputation is understood as the aggregate perception of how well an organization responds to its stakeholders' demands and expectations [22]. The concept of reputation also refers to the composite of ideas held by external audiences that play an important role in the development and success of a place [23]. A destination with a favorable reputation can be perceived as more credible and reliable relative to a destination with a poor reputation [16]. A favorable reputation can positively influence the tourist intention with a destination [24,25], also affecting tourist satisfaction [26] and destination image [27]. For its part, tourist satisfaction is understood as an individual cognitive-affective state derived from a tourist experience [28], and has also presented direct and positive effects on intentions [17]. Other previous studies indicate the positive effect of image destination on tourist intention $[14,18,19,29]$. Dutton and Dukerich [30] defined image as the way organization members believe others see their organization. Finally, Yüksel and Akgül [20] point out that people tend to develop a better intention with a destination if they have developed more favorably their cognitive perception, understood as the way in which the passengers perceive the attributes of a tourism destination [31]. These attributes include the place's landscape, attractions, services and infrastructure. 
On the other hand, as antecedents of the destination's reputation, the previous literature points out both the cognitive perception [21] and the familiarity [16,32,33]. Familiarity can be defined as the knowledge of what, why, where and when others do what they do [34]. Therefore, familiarity is a broad construct where knowledge about the organization can be resourced from sources as varied as the individual's first visits to the destination, the media, word of mouth, or publicity [35]. And in respect to the image, the literature points out the effects produced by the cognitive perception [36-38], familiarity $[16,32]$ and affective evaluation $[16,39,40]$. An affective evaluation is a set of positive, neutral, or negative emotional association with a place. People have emotional responses to different places and transform these emotions into images and memories [41].

In the literature that analyzes the sustainability of port of call destination, the cruise passengers' intention is also the main variable studied. However, the analysis models used have been very simple, considering only two of the antecedents proposed by the generic literature on tourist destination. Some authors thought that the antecedent of the cruise passengers' intention is the satisfaction with a port of call [5,10-13,42], and that in turn, this is formed by the cognitive perception of those who have experienced it. Sanz and Carvajal also observed the mediating effect of the image between cognitive perception and satisfaction [10].

Therefore, and taking into account that the literature on sustainability of tourist destination references a wide set of variables that may have an impact on the tourist intention, but that existing studies on cruises address this issue initially and with limitations, in the present study the hypotheses that appear below are established in order to respond to the research question, that is, to build a robust model for analysis of the cruise passengers' intention (Figure 2).

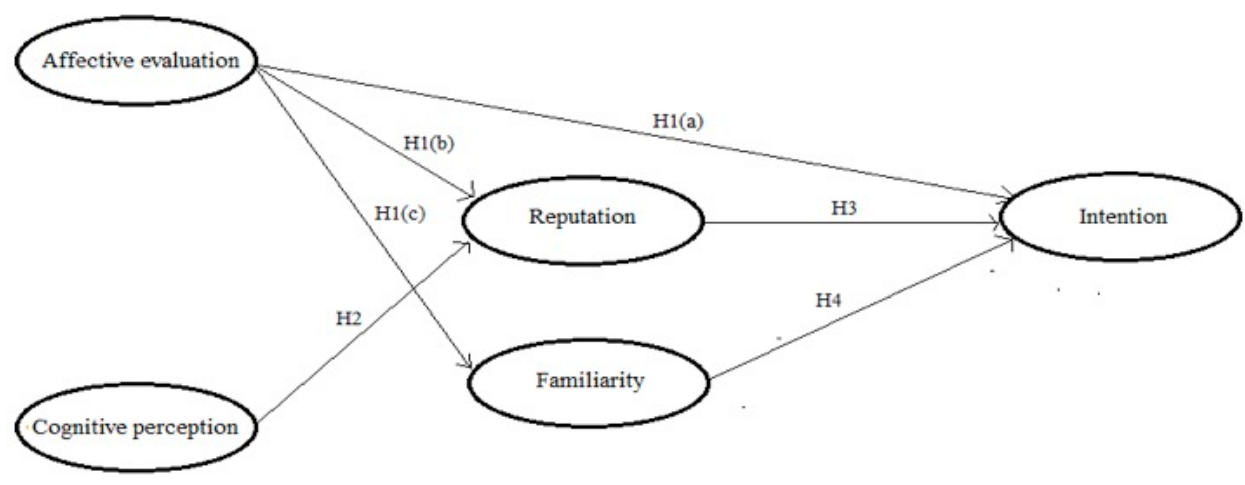

Figure 2. Research model and hypotheses.

The first research hypothesis to be contrasted in the present study arises as a consequence of the effects that affective evaluation has shown in the previous literature on tourist intention $[16,19,32,39,40,43]$. Therefore, we posit that:

Hypothesis 1 (H1). The affective evaluation that cruise passengers have of a port of call is related to cruise passengers' intention.

The hypothesis $\mathrm{H} 1$ is expressed, in turn, through three sub-hypotheses:

Hypothesis 1a (H1a). The affective evaluation that cruise passengers have of a port of call has a positive effect on cruise passengers' intention.

Hypothesis $\mathbf{1 b} \mathbf{( H 1 b )}$. The affective evaluation that cruise passengers have of a port of call has a positive effect on port of call reputation.

Hypothesis 1c (H1c). The affective evaluation that cruise passengers have of a port of call has a positive effect on familiarity with a port of call. 
The second research hypothesis is a consequence of the relationship between cognitive perception and reputation [21], and we want to check if the cognitive perception is an antecedent of the port of call reputation. The hypothesis will be:

Hypothesis 2 (H2). The cognitive perception that cruise passengers have of a port of call has a positive effect on port of call reputation.

On the other hand, the third of the hypotheses refers to reputation as the antecedent of the intention [25], and tries to contrast if there is a relationship between port of call reputation and cruise passengers' intention. Hence, we posit that:

Hypothesis 3 (H3). The port of call reputation has a positive effect on cruise passengers' intentions.

Finally, the fourth hypothesis refers to the effect of familiarity on intentions [16], and tries to test whether this effect is significant for cruise passengers. Accordingly, we posit that:

Hypothesis 4 (H4). The familiarity with a port of call has a positive effect on cruise passengers' intention.

\section{Survey data}

\subsection{The Malaga Port of Call}

Malaga has recently undergone intense development as a port of call [44]. The number of cruise passengers visiting the port has increased from 162,803 in 2002 to more than 509,644 in 2017. The cruise industry not only has a high economic impact on the city, but may also affect its future growth. This port is still relatively young and has great potential for further development. It has competitive advantages, such as a geostrategic location that can be used for Mediterranean, Atlantic, and Mediterranean-Atlantic routes (Figure 3). The city also has excellent transportation services (by air, railway, and road) and strong hospitality industry (e.g., hotels, restaurants, and museums), which welcome thousands of tourists from different segments. Nevertheless, the tourist offer of Malaga is not yet sufficiently cruise passenger-oriented, and public and private resources for its promotion remain scarce. However, the port of Malaga has recently undergone marked changes that include the creation of new piers and new technical and commercial facilities that have helped meet the challenge of the growing tourist demand. Malaga has two main goals as a port of call destination: To increase the number of times it is used as port of call and chosen as a home port; and to increase cruise tourist spending in the city.

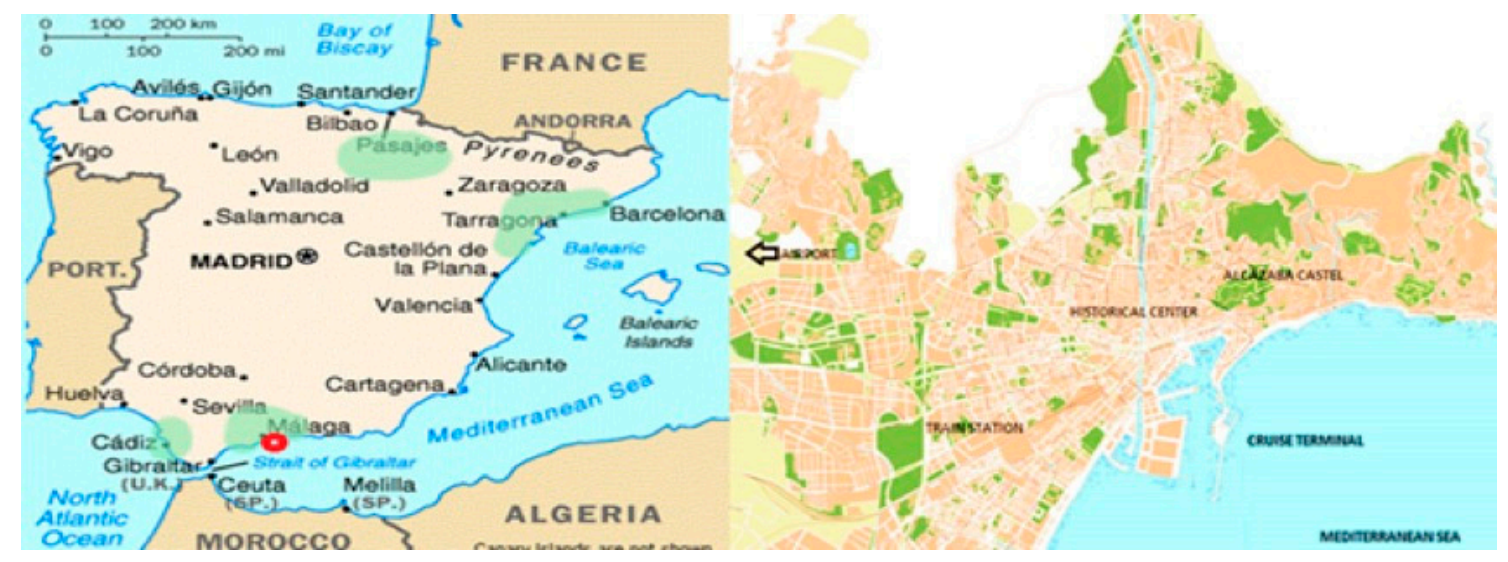

Figure 3. Location of Malaga and the cruise terminal. 


\subsection{Description of the Survey}

The questionnaire used in the current study was based on a review of the literature $[5,10-13,16,17,45]$. The questionnaire was designed in four languages (Spanish, English, French, and German) and was grouped into two sections (Table 1). The first section included questions on the respondents' profile and sociodemographic variables (age, gender, marital status, education, income, geographic origin, spending, and the number of previous visits to the city). The second section investigated reputation, affective evaluation, cognitive perception, familiarity, and intention, using a ten-point Likert-type scale ranging from 1 (very poor) to 10 (excellent). This type of scale was chosen because of the need to conduct subsequent statistical tests suited to the metric variables (average, standard deviation). Theoretically, a wider scale offers a greater range of responses and makes it easier to apply the statistical procedures previously mentioned. It also offers greater measurement accuracy, improved sensitivity to detect changes, and greater explanatory power. This scale was also used by Petrick and Sirakaya [46].

Table 1. Questionnaire items.

\begin{tabular}{|c|c|c|}
\hline Code & Description & Source \\
\hline \multicolumn{3}{|c|}{ Reputation } \\
\hline Rep1 & Malaga has good reputation & \multirow{4}{*}[13,16]{} \\
\hline $\operatorname{Rep} 2$ & This place has a better reputation than other similar places & \\
\hline Rep3 & People respect this place highly & \\
\hline Rep4 & People speak very well of this place & \\
\hline \multicolumn{3}{|c|}{ Affective evaluation } \\
\hline Aff1 & I have affection for this place & \multirow{4}{*}[13,16]{} \\
\hline Aff2 & This place gives me a sense of joy & \\
\hline Aff3 & This place makes me feel good & \\
\hline Aff 4 & This place gives me happiness & \\
\hline \multicolumn{3}{|c|}{ Cognitive perception } \\
\hline $\operatorname{Cog} 1$ & Rate the variety of things to see and do & \multirow{6}{*}[10,11,13,16]{} \\
\hline $\operatorname{Cog} 2$ & Rate the hospitality of the city's inhabitants & \\
\hline $\operatorname{Cog} 3$ & Rate the quality of service in restaurants & \\
\hline $\operatorname{Cog} 4$ & Rate the variety of shops and fashion stores & \\
\hline $\operatorname{Cog} 5$ & Rate the service at tourist information centers & \\
\hline $\operatorname{Cog} 6$ & Rate road traffic in Malaga & \\
\hline \multicolumn{3}{|c|}{ Familiarity } \\
\hline Fam1 & This place is very familiar to me & \multirow{4}{*}{ [16] } \\
\hline Fam2 & Have your friends ever talked to you about Malaga? & \\
\hline Fam3 & Malaga according to info coming from social networks and Internet & \\
\hline Fam4 & Have you heard of Malaga through some advertising campaign? & \\
\hline \multicolumn{3}{|l|}{ Intention } \\
\hline Revis1 & High likelihood of revisiting Malaga & \multirow{7}{*}[5,11-13,17]{} \\
\hline Revis2 & Will Malaga be your first choice for future trips? & \\
\hline Revis3 & Would you visit Malaga if with a higher price than other destinations? & \\
\hline Revis4 & Would you come back to Malaga despite a modest increase in prices? & \\
\hline Wom1 & Would you encourage your friends to come to Malaga? & \\
\hline Wom2 & Will you say positive things about Malaga? & \\
\hline Wom3 & Refer Malaga tour to other people? & \\
\hline
\end{tabular}

The target population comprised passengers who stopped at the port of Malaga during their cruise between 22nd January 2018 and 12th December 2018. During this period, 242 cruise ships with 182,038 passengers called at the port of Malaga. To obtain a representative sample of the population, we selected 24 cruise ships that stopped at the port during this period. The sample included a balanced representation of both the luxury and standard segments in relation to the total number of passengers, and the main passengers' nationalities. 
Data collection was conducted by trained interviewers and directly supervised by the co-authors of this study and the port administrators of the regional government. The interviewers received training on administering the questionnaire and obtaining answers from the respondents. All data were obtained at the Malaga cruise terminal when the passengers were about to re-board after their stop-off. The focal sampling method was used to intercept passengers when entering the study area [47]. Focal sampling is conducted by intercepting the first person encountered in the predetermined study area. Once the interviewer has interviewed the respondent, he or she approaches the next person entering the zone. A total of 392 surveys were completed (margin of error: Less than 5\%; level of accuracy: 95\%).

\subsection{Passenger Profile}

Table 2 shows the profiles of the passengers who voluntarily participated in the study. The majority of the respondents were male $(59.69 \%)$, between $30-50$ years of age $(41.58 \%)$, and single $(53.83 \%)$. Around $40 \%$ of the respondents had a university degree and $29.59 \%$ had postgraduate studies. Around $65 \%$ of the respondents earned more than $\$ 25,000$ per year; of these, $20.67 \%$ earned more than $\$ 50,000$ per year. These results are in line with those of Adriotis and Agiomirgianakis [11], who suggested that income and educational level are associated with the capacity to cover the costs of a cruise.

Table 2. Cruise passenger profiles of the sample.

\begin{tabular}{|c|c|c|c|c|c|c|}
\hline & \multicolumn{2}{|c|}{ Total Cruises } & \multicolumn{2}{|c|}{ Luxury Cruises } & \multicolumn{2}{|c|}{ Standard Cruises } \\
\hline & $\mathrm{n}$ & $\%$ & $\mathrm{n}$ & $\%$ & $\mathrm{n}$ & $\%$ \\
\hline \multicolumn{7}{|l|}{ Gender } \\
\hline Male & 234 & 59.69 & 79 & 58.51 & 155 & 60.31 \\
\hline Female & 158 & 40.31 & 56 & 41.49 & 102 & 39.69 \\
\hline \multicolumn{7}{|l|}{ Age } \\
\hline Under 30 years & 104 & 26.53 & 28 & 20.74 & 76 & 29.57 \\
\hline $30-50$ years & 163 & 41.58 & 58 & 42.96 & 105 & 40.86 \\
\hline 50-65 years & 76 & 19.39 & 37 & 27.40 & 39 & 15.17 \\
\hline Over 65 years & 49 & 12.50 & 12 & 8.90 & 37 & 14.40 \\
\hline \multicolumn{7}{|l|}{ Marital status } \\
\hline Married & 181 & 46.17 & 60 & 44.44 & 121 & 47.08 \\
\hline Single & 168 & 53.83 & 75 & 55.56 & 93 & 52.92 \\
\hline \multicolumn{7}{|l|}{ Education } \\
\hline Primary & 34 & 8.67 & 12 & 8.89 & 22 & 8.56 \\
\hline Secondary & 84 & 21.43 & 28 & 20.74 & 56 & 21.79 \\
\hline University & 158 & 40.31 & 46 & 34.07 & 112 & 43.58 \\
\hline Postgraduate & 116 & 29.59 & 49 & 36.30 & 67 & 26.07 \\
\hline \multicolumn{7}{|l|}{ Income } \\
\hline Less than $\$ 25,000$ & 138 & 35.20 & 30 & 22.22 & 108 & 42.02 \\
\hline Between $\$ 25,001-50,000$ & 173 & 44.13 & 72 & 53.33 & 101 & 39.30 \\
\hline$\$ 50,001$ or more & 81 & 20.67 & 33 & 24.45 & 48 & 18.68 \\
\hline \multicolumn{7}{|l|}{ First visit to Malaga } \\
\hline Yes & 312 & 79.59 & 102 & 75.55 & 210 & 81.71 \\
\hline No & 80 & 20.41 & 33 & 24.45 & 47 & 18.29 \\
\hline \multicolumn{7}{|l|}{ Nationality } \\
\hline German & 63 & 16.07 & 11 & 8.15 & 52 & 20.23 \\
\hline British & 46 & 11.73 & 11 & 8.15 & 35 & 13.62 \\
\hline Italian & 42 & 10.71 & 11 & 8.15 & 31 & 12.06 \\
\hline North American & 35 & 8.93 & 25 & 18.52 & 10 & 3.89 \\
\hline Other & 206 & 52.56 & 77 & 42.97 & 129 & 50.20 \\
\hline
\end{tabular}

Note: Luxury cruises: Cruise ships that carry 50 to 100 passengers; Standard cruises: Cruise ships that carry more than 100 passengers [48]. 
The 392 respondents were divided by geographical origin. German and British passengers were highly represented $(16.07 \%$ and $11.73 \%$, respectively). The findings show that passengers from European countries were the most frequent visitors to the Malaga port of call. Despite the high representation of German and British passengers, proximity to the destination may not imply certain behavior patterns: European passengers may have either made a cruise or combined a cruise with a land-based holiday. Andriotis and Agiomirgianakis [11] obtained similar results regarding the Heraklion port of call and the Americas.

The main differences between passenger characteristics by cruise segment were related to income level and nationality. The income structure of the luxury segment passengers was higher than that of the standard segment. Most of the luxury segment passengers were from North America (23.01\%). However, European passengers predominated in the standard segment (20.23\% were German and $13.62 \%$ were British).

\section{Results}

\subsection{Statistical Procedure}

Our research model has been tested using Partial Least Squares (PLS), a variance-based Structural Equation Modelling (SEM) [49]. PLS is particularly suitable to test the proposed theoretical model, because it allows simultaneous estimation of multiple relationships between latent constructs involving hierarchical variables and accounts for measurement error in the constructs [50]. PLS analyses are more flexible than Covariance-Based SEM in order to model both reflective and formative latent factors at the same time [51,52]. In addition, PLS-SEM simultaneously allows assessment of the reliability and validity of the measures of theoretical constructs (outer or measurement model) and the estimation of the relationships between these constructs (inner model) [53,54]. PLS-SEM is primarily intended for causal-predictive analysis, where the problems explored are complex and prior theoretical knowledge is scarce [55]. Consequently, PLS-SEM is an appropriate technique to use in a theory development situation, such as in this study [54,56]. Traditional PLS is preferable, because the study uses second order models and does not have a sufficiently large data set [57]. This study uses Smart PLS 3.2.7 software [58].

\subsection{Model Validation}

Each variable in the model was measured by multiple indicators and evaluated in terms of reliability, nomological validity and composition weights [59]. We assess our measurement model by assessing VIF values for collinearity issues, as well as the significance and relevance of indicators [50]. Significances were obtained by a nonparametric (5000) bootstrap procedure. Further, we assessed the predictive ability by using the blindfolding procedure in Smart PLS in order to check that cross-validated communalities and redundancies Q2 are superior to 0 [60]. Reliability and convergent validity of measures are shown in Table 3. Most of our reflective indicators load on their respective constructs more than 0.71 [61]. However, there are two items which have loadings from 0.61 to 0.63, but these loadings may be acceptable [62] if their rejection does not improve the model fit [50]. Moreover, all the reliability indicators exceed their shortcut values. Likewise, as shown in Table 4, discriminant validity was assessed using cross-loadings (not reported), the Fornell-Larcker criterion, and the HTMT criterion in variance-based SEM. 
Table 3. Convergent validity and reliability of measures.

\begin{tabular}{|c|c|c|c|c|c|c|c|c|}
\hline & Indicator & Loadings $^{*}$ & $q^{2}$ & $\mathrm{Q}^{2}$ & $\alpha$ & $\rho_{\mathrm{A}}$ & CR & AVE \\
\hline \multirow{5}{*}{ Affective evaluation (LOC1) } & & & & & & & & \\
\hline & Aff1 & 0.83 & & & 0.92 & 0.93 & 0.95 & 0.81 \\
\hline & Aff2 & 0.95 & & & & & & \\
\hline & Aff3 & 0.93 & & & & & & \\
\hline & Aff4 & 0.90 & & & & & & \\
\hline \multirow{6}{*}{ Cognitive perception (LOC2) } & $\operatorname{Cog} 1$ & 0.77 & & & 0.85 & 0.86 & 0.89 & 0.57 \\
\hline & $\operatorname{Cog} 2$ & 0.81 & & & & & & \\
\hline & $\operatorname{Cog} 3$ & 0.80 & & & & & & \\
\hline & $\operatorname{Cog} 4$ & 0.79 & & & & & & \\
\hline & $\operatorname{Cog} 5$ & 0.73 & & & & & & \\
\hline & $\operatorname{Cog} 6$ & 0.63 & & & & & & \\
\hline \multirow[t]{4}{*}{ Reputation (LOC3) } & Rep1 & 0.87 & 0.36 & 0.35 & 0.90 & 0.90 & 0.93 & 0.77 \\
\hline & Rep2 & 0.85 & 0.31 & 0.30 & & & & \\
\hline & Rep3 & 0.89 & 0.39 & 0.38 & & & & \\
\hline & $\operatorname{Rep} 4$ & 0.90 & 0.44 & 0.41 & & & & \\
\hline \multirow[t]{4}{*}{ Familiarity (LOC4) } & Fam1 & 0.79 & 0.17 & 0.16 & 0.85 & 0.85 & 0.90 & 0.69 \\
\hline & Fam2 & 0.87 & 0.14 & 0.15 & & & & \\
\hline & Fam3 & 0.87 & 0.16 & 0.16 & & & & \\
\hline & Fam4 & 0.80 & 0.07 & 0.08 & & & & \\
\hline \multirow[t]{4}{*}{ Revisit (LOC5) } & Revis1 & 0.71 & 0.30 & 0.32 & 0.88 & 0.89 & 0.93 & 0.81 \\
\hline & Revis2 & 0.88 & 0.23 & 0.43 & & & & \\
\hline & Revis3 & 0.89 & 0.13 & 0.33 & & & & \\
\hline & Revis4 & 0.82 & 0.17 & 0.31 & & & & \\
\hline \multirow[t]{3}{*}{ Word-of-mouth (LOC6) } & Wom2 & 0.92 & 0.37 & 0.42 & 0.85 & 0.85 & 0.90 & 0.69 \\
\hline & Wom3 & 0.94 & 0.38 & 0.43 & & & & \\
\hline & Wom4 & 0.85 & 0.26 & 0.32 & & & & \\
\hline \multicolumn{9}{|l|}{ High Order Construct } \\
\hline \multirow[t]{2}{*}{ Intention(HOC) } & Revisit & 0.90 & 0.30 & 0.51 & 0.76 & 0.76 & 0.89 & 0.80 \\
\hline & Word-of-mor & uth 0.89 & 0.42 & 0.47 & & & & \\
\hline
\end{tabular}

Note: $\mathrm{q}^{2}$ : PLS-predict $\mathrm{q}^{2}$ index; $\mathrm{Q}^{2}$ : Cross-Validated Redundancies Stone-Geisser $\mathrm{Q}^{2}$ index; $\alpha$ : Cronbach's alpha; $\rho A$ : [63] Rho; CR: Composite Reliability; AVE: Average Variance Extracted; High Order Construct made in a two-steps procedure from LOC5 and LOC6; *: All loadings are significant at $p<0.001$ level.

Table 4. Discriminant validity.

\begin{tabular}{lcccccccc}
\hline & & LOC1 & LOC2 & LOC3 & LOC4 & LOC5 & LOC6 & HOC \\
\hline LOC1 & Affective evaluation & $\mathbf{0 . 9 0}$ & 0.80 & 0.71 & 0.52 & 0.62 & 0.70 & 0.79 \\
LOC2 & Cognitive perception & 0.71 & $\mathbf{0 . 7 6}$ & 0.75 & 0.48 & 0.60 & 0.67 & 0.76 \\
LOC3 & Reputation & 0.65 & 0.66 & $\mathbf{0 . 8 8}$ & 0.36 & 0.67 & 0.67 & 0.81 \\
LOC4 & Familiarity & 0.46 & 0.41 & 0.32 & $\mathbf{0 . 8 3}$ & 0.72 & 0.58 & 0.77 \\
LOC5 & Revisit & 0.55 & 0.51 & 0.59 & 0.61 & $\mathbf{0 . 8 3}$ & 0.71 & - \\
LOC6 & Word of mouth & 0.63 & 0.58 & 0.60 & 0.51 & 0.61 & $\mathbf{0 . 9 0}$ & - \\
HOC & Intention & 0.66 & 0.61 & 0.67 & 0.62 & - & - & $\mathbf{0 . 9 0}$ \\
\hline
\end{tabular}

Note: Correlations below the diagonal; Squared-root of AVE in the diagonal (bold) to assess Fornell-Lacker criterion.

\subsection{Structural Model}

A blindfolding procedure $[64,65]$ reveal cross-validated redundancies Stone-Geisser $\mathrm{Q}^{2}$ values ranging [0.12-0.49] for a distance-omission of 7. This finding provides support for the model's overall predictive relevance, since the Q2 values are above 0 [65]. Moreover, PLS-predict $\mathrm{q}^{2}$ indexes range [0.001-0.460]. As a second quality assessment this study assesses the standardized root mean square residual (SRMR) as a goodness-of-fit indicator for the structural model. A value less than 0.08 reflect a good fit for SRMR [66,67]. Additionally, SRMR, as well as unstandardized least squares either geodesian discrepancies values, are into the two-tailed 95\% confidence interval [59]. Also, both $\mathrm{R}^{2}$ and adjusted $R^{2}$ are superior to 0.10 . These results may indicate a well-constructed model, suggesting that our theoretical model is true $[59,63]$. See Table 5 for details. 
Table 5. Inner model results and validation criteria.

\begin{tabular}{|c|c|c|c|c|c|c|c|c|c|}
\hline \multirow{2}{*}{$\begin{array}{c}\text { Second Stage Inner Model } \\
\text { Affective evaluation } \rightarrow \text { Reputation }\end{array}$} & \multicolumn{2}{|c|}{ Paths } & \multirow{2}{*}{$\begin{array}{c}\text { St. Dev. } \\
0.09\end{array}$} & \multicolumn{3}{|c|}{$95 \%$ conf. int. } & \multicolumn{2}{|r|}{$\mathrm{f}^{2}$} & \multirow{2}{*}{$\begin{array}{r}\text { VIF } \\
2.02\end{array}$} \\
\hline & 0.37 & $* * *$ & & {[} & 0.20 & 0.53 & ] & 0.13 & \\
\hline Affective evaluation $\rightarrow$ Familiarity & 0.46 & $* * *$ & 0.08 & ] & 0.29 & 0.59 & ] & 0.27 & 1.00 \\
\hline Affective evaluation $\rightarrow$ Intention & 0.21 & * & 0.09 & L & 0.02 & 0.38 & ] & 0.07 & 1.98 \\
\hline Cognitive perception $\rightarrow$ Reputation & 0.40 & $* * *$ & 0.07 & {[} & 0.24 & 0.54 & ] & 0.16 & 2.02 \\
\hline Reputation $\rightarrow$ Intention & 0.40 & $* * *$ & 0.06 & {[} & 0.27 & 0.52 & ] & 0.27 & 1.74 \\
\hline Familiarity $\rightarrow$ Intention & 0.40 & $* * *$ & 0.10 & {[} & 0.22 & 0.58 & ] & 0.35 & 1.27 \\
\hline \multicolumn{10}{|l|}{ Overall validation criteria } \\
\hline SRMR & 0.06 & $* * *$ & 0.007 & [ & 0.04 & 0.07 & ] & & \\
\hline $\mathrm{d}_{\mathrm{ULS}}$ & 0.95 & $* * *$ & 0.16 & [ & 0.43 & 1.04 & ] & & \\
\hline $\mathrm{d}_{\mathrm{G}}$ & 0.50 & $* * *$ & 0.06 & [ & 0.29 & 0.51 & ] & & \\
\hline \multicolumn{10}{|l|}{$\mathrm{R}^{2}$} \\
\hline Intention & 0.65 & $* * *$ & 0.05 & [ & 0.53 & 0.73 & ] & & \\
\hline Familiarity & 0.21 & $* *$ & 0.07 & [ & 0.08 & 0.35 & ] & & \\
\hline Reputation & 0.51 & $* * *$ & 0.06 & l & 0.37 & 0.62 & ] & & \\
\hline \multicolumn{10}{|l|}{ Adjusted $\mathrm{R}^{2}$} \\
\hline Intention & 0.65 & $* * *$ & 0.05 & [ & 0.52 & 0.72 & ] & & \\
\hline Familiarity & 0.21 & $* *$ & 0.07 & [ & 0.08 & 0.35 & ] & & \\
\hline Reputation & $\begin{array}{l}0.50 \\
q^{2}\end{array}$ & $* * *$ & $\begin{array}{l}0.06 \\
Q^{2}\end{array}$ & [ & 0.36 & 0.62 & ] & & \\
\hline Intention & 0.39 & & 0.49 & & & & & & \\
\hline Familiarity & 0.01 & & 0.14 & & & & & & \\
\hline Reputation & 0.46 & & 0.36 & & & & & & \\
\hline Chi-squared & 449.8 & & & & & & & & \\
\hline
\end{tabular}

Note: Original path values, as well as 5000 rep; Bootstrapping Standard Deviations and $95 \%$ bias-corrected confidence intervals reported; $\mathrm{q}^{2}$ : PLS-predict $\mathrm{q}^{2}$ index; $\mathrm{Q}^{2}$ : Cross-Validated Redundancies Stone-Geisser $\mathrm{Q}^{2}$ index; $*: p<0.05 ; * *: p<0.01 ; * * *: p<0.001$.

The results obtained suggest that affective evaluation had a positive and significant impact on intention (path $=0.21^{*}$ ), on reputation (path $=0.37^{* * *}$ ), and on familiarity (path $=0.46^{* *}$ ), suggesting that $\mathrm{H} 1(\mathrm{a}), \mathrm{H} 1(\mathrm{~b})$ and $\mathrm{H} 1$ (c) can be accepted. Likewise, the cognitive perception had a positive and significant impact on reputation (path $=0.40^{* * *}$ ), and so $\mathrm{H} 2$ is accepted. In addition, reputation and familiarity show a positive and significant impact on the intention (path $=0.40^{* * *}$ and path $=0.40^{* * *}$, respectively), so $\mathrm{H} 3$ and $\mathrm{H} 4$ are also accepted. Path coefficients and their bootstrapping significance levels are reported in Figure 4.

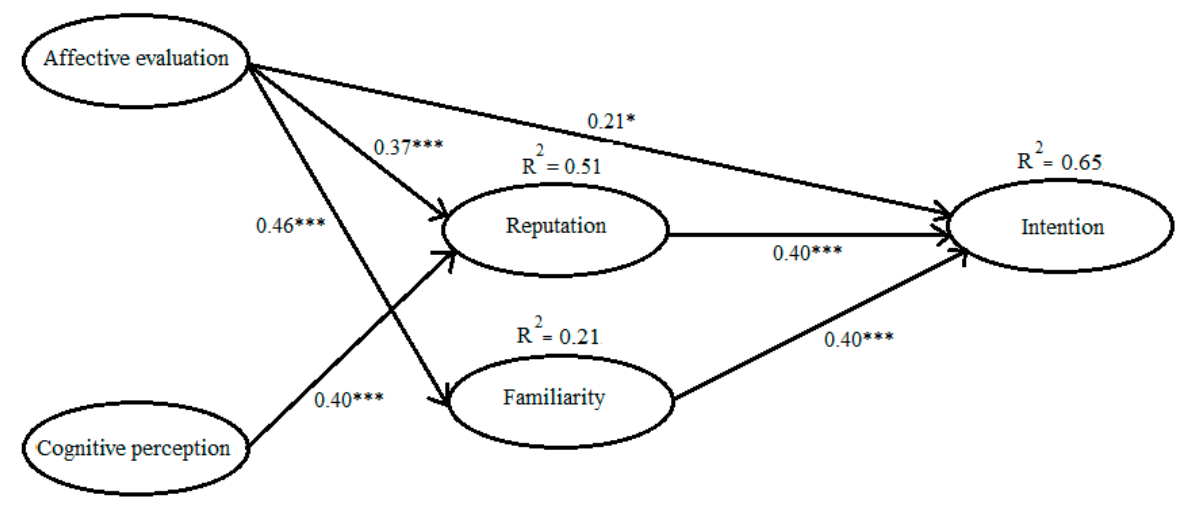

Figure 4. Structural model results. 


\section{Discussion}

This study has analyzed the cruise passengers' intention with a port of call destination. Initially, all the antecedents that have been significant in both the generic literature on sustainable tourist destination and in that exclusively related to port of call destination have been considered. The results obtained show that the antecedents of cruise passengers' intention are reputation and familiarity port of call. However, these results are different from those of the previous cruise literature. For example, Pranic, Meng, Petrick, and Andriotis and Agiomirgianakis [5,11-13] indicate, as the only antecedent, the cruise passengers' satisfaction. Also, Sanz and Carvajal [10] indicate as antecedent, in addition to satisfaction, the port of call image. These differences with respect to the previous literature on cruises may be due to the fact that existing studies have used very simple analysis models, which only include some of the variables that could potentially be the antecedent of cruise passengers' intention. Moreover, because they have used relatively small samples, a few limited ships, or short periods of time.

On the other hand, the present study has found that affective evaluation has a positive effect on the reputation and familiarity of the port of call. And affective evaluation had never been considered in previous studies on cruise passengers' intention. Only Petrick [13] considered a similar variable - emotional response - but related to cruise passengers' satisfaction, not the intention.

Finally, the results of our model also indicate that cognitive perception is another variable that has a positive effect on port of call reputation. But, in the previous studies referring to cruises, this variable has only shown effects on cruise passengers' satisfaction [11,13], and port of call image [10]. Again, the differences in results may be due to the amplitude of the sample and the complete set of variables that, as possible antecedents of cruise passengers' intention, were used in the present study.

\section{Conclusions}

\subsection{Theoretical Contributions}

Currently, cruise tourism is having a strong economic impact on the Mediterranean region. Cruise destinations can achieve greater economic development depending on the intentions of passengers to visit them again and recommend them. Previous literature suggests that different variables may influence the cruise passengers' intention regarding port of call. However, current studies on this issue only offer an initial and limited analysis on the antecedents of this intention. Thus, this study investigated the intention of cruise passengers who visited a port of call in the Mediterranean (Malaga, Spain). With this objective, a model based on the antecedents of cruise passengers' intention has been constructed. The results show that the affective evaluation with a port of call has a positive effect on cruise passengers' intention through reputation and familiarity. Also, that cognitive perception influences intention through reputation. Therefore, we suggest that much of the port of calls sustainability depends on its implementation of actions that improve its reputation and its familiarity.

This study provides three important contributions to sustainable tourism literature. First, it overcame some of the limitations in previous cruise studies by analyzing the antecedents of cruise passengers' intention with the port of call. Second, it examined the structure of the reputation-familiarity-intention for port of call destination. Third, this study presented empirical evidence of a great time period that covers a large number of ships, ship owners, segments and passenger nationalities.

\subsection{Practical Contributions}

From an applied perspective, this research shows implications for helping port of call managers to improve sustainability. The results suggest that port managers should implement strategies that improve the experiences and emotions of passengers, particularly those related to the variety of things to see and do, the hospitality of the city's inhabitants, the quality of service in restaurants, variety of shops and fashion stores, and tourist information centers. Such strategies would improve port of call reputation and would influence cruise passengers' intentions, thereby increasing economic 
activity. They could also develop advertising and social media strategies to increase familiarity with the destination.

The results could also be used to improve the actions and marketing plans of the ports of call. On the one hand, developing advertising strategies and social networks that increase the familiarity of tourists with the destination. On the other hand, conducting promotional campaigns aimed at ship owners, highlighting both the destination' reputation and the aspects best valued by cruise passengers.

\subsection{Future Research Directions}

Future research could address the issues of reputation and familiarity in other cultural contexts (e.g., other Mediterranean and Caribbean ports of call) to analyze possible variations in the antecedent factors that affect the destination and the passengers' future intentions. Comparative studies of passenger intention and their behavior would make it possible to quantify the effect of reputation and familiarity on the sustainability of the port of call.

Author Contributions: This study has been designed and performed by all of the authors. M.A.F. and J.R.S. collected the data. The introduction and hypothesis were written by M.A.F. and J.R.S., the literature review by A.J.C. and A.C. All of the authors analyzed the data, and wrote the results, discussion and conclusions.

Funding: This research received no external funding.

Conflicts of Interest: The authors declare no conflict of interest.

\section{References}

1. CLIA. Annual Report 2017. Available online: https://www.cruising.org/about-the-industry/research/2017annual-report (accessed on 15 November 2018).

2. Lester, J.A.; Weeden, C. Stakeholders, the natural environment and the future of Caribbean cruise tourism. Int. J. Tour. Res. 2004, 6, 39-50. [CrossRef]

3. Chang, Y.T.; Lee, S.; Park, H. Efficiency analysis of major cruise lines. Tour. Manag. 2017, 58, 78-88. [CrossRef]

4. Papathanassis, A.; Bechmann, I. Assessing the Poverty of Cruises Theory Hypothesis. Ann. Tour. Res. 2011, 38, 153-174. [CrossRef]

5. Pranić, L.; Marušić, Z.; Sever, I. Cruise passengers' experiences in coastal destinations-floating "B\&Bs" vs. floating "resorts": A case of Croatia. Ocean Coast. Manag. 2013, 84, 1-12.

6. Yarnal, C.M.; Kerstetter, D. Casting off an exploration of cruise ship space, group tour behavior, and social interaction. J. Travel Res. 2005, 43, 368-379. [CrossRef]

7. Petrick, J.F. Segmenting cruise passengers with price sensitivity. Tour. Manag. 2005, 26, 753-762. [CrossRef]

8. Kurtzman, J. Economic impact: Sport tourism and the city. J. Sport Tour. 2005, 10, 47-71. [CrossRef]

9. Papathanassis, A. Cruise tourism management: State of the art. Tour. Rev. 2017, 72, 104-119. [CrossRef]

10. Sanz, S.; Carvajal-Trujillo, E. Cruise passengers' experiences in a Mediterranean port of call. The case study of Valencia. Ocean Coast. Manag. 2014, 102, 307-316. [CrossRef]

11. Andriotis, K.; Agiomirgianakis, G. Cruise visitors' experience in a Mediterranean port of call. Int. J. Tour. Res. 2010, 12, 390-404. [CrossRef]

12. Meng, S.M.; Liang, G.S.; Yang, S.H. The relationships of cruise image, perceived value, satisfaction, and post-purchase behavioral intention on Taiwanese tourists. Afr. J. Bus. Manag. 2011, 5, 19-29.

13. Petrick, J.F. The roles of quality, value, and satisfaction in predicting cruise passengers' behavioral intentions. J. Travel Res. 2004, 42, 397-407. [CrossRef]

14. Martín-Santana, J.D.; Beerli-Palacio, A.; Nazzareno, P.A. Antecedents and consequences of destination image gap. Ann. Tour. Res. 2017, 62, 13-25. [CrossRef]

15. Petrick, J.F. Segmenting cruises passengers with perceived reputation. J. Hosp. Tour. Manag. 2011, 18, 48-53. [CrossRef]

16. Artigas, E.M.; Vilchez-Montero, S.; Yrigoyen, C.C. Antecedents of tourism destination reputation: The mediating role of familiarity. J. Retail. Consum. Serv. 2015, 26, 147-152. [CrossRef]

17. Kim, Y.H.; Kim, D.J.; Wachter, K. A study of mobile user engagement (MoEN): Engagement motivations, perceived value, satisfaction, and continued engagement intention. Decis. Support Syst. 2013, 56, 361-370. [CrossRef] 
18. Acosta Pereira, L.; Flôres Limberger, P.; Da Silva Flores, L.C.; De Lima Pereira, M. An Empirical Investigation of Destination Branding: The Case of the City of Rio de Janeiro, Brazil. Sustainability 2019, 11, 90. [CrossRef]

19. Assaker, G.; Vinzi, V.E.; O'Connor, P. Examining the effect of novelty seeking, satisfaction, and destination image on tourists' return pattern: A two factor, non-linear latent growth model. Tour. Manag. 2011, 32, 890-901. [CrossRef]

20. Yüksel, A.; Akgül, O. Postcards as affective image markers: An idle agent in destination marketing. Tour. Manag. 2007, 28, 714-725. [CrossRef]

21. Walsh, G.; Wiedmann, K.P. A conceptualization of corporate reputation in Germany: An evaluation and extension of the RQ. Corp. Reput. Rev. 2004, 6, 304-312. [CrossRef]

22. Wartick, S.L. Measuring corporate reputation: Definition and data. Bus. Soc. 2002, 41, 371-392. [CrossRef]

23. Nelson, V. Place reputation: Representing Houston, Texas as a creative destination through culinary culture. Tour. Geogr. 2015, 17, 192-207. [CrossRef]

24. Lee, S.; Nguyen, H.N.; Lee, K.S.; Chua, B.L.; Han, H. Price, people, location, culture and reputation: Determinants of Malaysia as study destination by international hospitality and tourism undergraduates. J. Tour. Cult. Chang. 2018, 16, 335-347. [CrossRef]

25. Christou, E. Tourist destinations as brands: The impact of destination image and reputation on visitor loyalty. In Productivity in Tourism: Fundamentals and Concepts for Archieving Growth and Competitiveness; Keller, P., Bieger, T., Eds.; Erich Schmidt Verlag: Berlin, Germany, 2007; pp. 57-67.

26. Loureiro, S.M.C.; Kastenholz, E. Corporate reputation, satisfaction, delight, and loyalty towards rural lodging units in Portugal. Int. J. Hosp. Manag. 2011, 30, 575-583. [CrossRef]

27. Micera, R.; Crispino, R. Destination web reputation as "smart tool" for image building: The case analysis of Naples city-destination. Int. J. Tour. Cities 2017, 3, 406-423. [CrossRef]

28. San Martín, H.; Rodríguez, L.A. Exploring the cognitive-affective nature of destination image and the role of psychological factors in its formation. Tour. Manag. 2008, 29, 263-277. [CrossRef]

29. Stepshenckova, S.; Mills, J. Destination image: A meta-analysis of 2000-2007 research. J. Hosp. Mark. Manag. 2010, 19, 575-609. [CrossRef]

30. Dutton, J.E.; Dukerich, J.M. Keeping an Eye on the Mirror: Image and Identity in Organizational Adaptation. Acad. Manag. J. 1991, 34, 517-554.

31. Beerlin, A.; Martin, J.D. Factors influencing destination image. Ann. Tour. Res. 2004, 31, 657-681. [CrossRef]

32. Langue, D.; Lee, P.M.; Dai, Y. Organizational reputation: A review. J. Manag. 2011, 37, 153-184. [CrossRef]

33. MacCorkindale, T. Does familiarity breed contempt? Analysis of the relationship among company familiarity, company reputation, company citizen-ship, and company personality on company equity. Public Relat. Rev. 2008, 34, 392-395.

34. Gefen, E. E-commerce: The role of familiarity and trust. Int. J. Manag. 2000, 28, 725-737. [CrossRef]

35. Johnson, E.J.; Russo, J.E. Product familiarity and learning new information. J. Consum. Res. 1984, 11, 542-550. [CrossRef]

36. Baloglu, S.; Mangodoglu, M. Tourism destination images of Turkey, Egypt, Greece, and Italy as perceived by US-based tour operators and travel agents. Tour. Manag. 2001, 22, 1-9. [CrossRef]

37. Kim, S.; Yoon, Y. The hierarchical effects of affective and cognitive components on tourism destination image. J. Travel Tour. Mark. 2003, 14, 1-22. [CrossRef]

38. Lin, C.H.; Morais, D.B.; Kerstetter, D.L.; Hou, S.J. Examining the role of cognitive and affective image in predicting choice across natural, developed, and theme-park destinations. J. Travel Res. 2007, 46, 183-194. [CrossRef]

39. Windmann, S.; Kutas, M. Electrophysiological correlates of emotion-induced recognition bias. J. Cogn. Neurosci. 2001, 13, 577-592. [CrossRef]

40. Treese, A.; Johansson, M.; Lindgren, M. Oh, it's you again: Memory interference from irrelevant emotional and neutral faces. Cogn. Emot. 2011, 25, 907-915. [CrossRef]

41. Milan, G.; Gasparin, F.; Toni, D. A configuração da imagem de um shopping center na percepção de consumidores locais. Rev. Eletrôn. Adm. 2013, 19, 83-114. [CrossRef] 
42. Silvestre, A.L.; Santos, C.M.; Ramalho, C. Satisfaction and behavioural intentions of cruise passengers visiting the Azores. Tour. Econ. 2008, 14, 169-184. [CrossRef]

43. Marinao, E.; Chasco, C.; Torres, E. Trust in tourist destinations. The role of local inhabitants and institutions. Rev. Latinoam. Adm. 2012, 51, 27-47.

44. Malagaport. Puerto de Málaga: Cierre del Ejercicio 2017. 2018. Available online: http:/ /www.malagaport. eu/estudios-e-informes / (accessed on 27 November 2018).

45. Chen, C.F.; Tsai, D. How destination image and evaluative factors affect behavioral intentions? Tour. Manag. 2007, 28, 1115-1122. [CrossRef]

46. Petrick, J.F.; Sirakaya, E. Segmenting cruisers by loyalty. Ann. Tour. Res. 2004, 31, 472-475. [CrossRef]

47. Groves, R.M.; Fowler, F.J.; Couper, M.P.; Lepkowski, J.M.; Singer, E.; Tourangeau, R. Survey Methodology; Wiley \& Sons: Hoboken, NJ, USA, 2010.

48. Diakomihalis, M.N. Chapter 13 Greek Maritime Tourism: Evolution, Structures and Prospects. Res. Transp. Econ. 2007, 21, 419-455. [CrossRef]

49. Reinartz, W.; Haenlein, M.; Henseler, J. An empirical comparison of the efficacy of covariance-based and variance-based SEM. Int. J. Res. Mark. 2009, 26, 332-344. [CrossRef]

50. Hair, J.F.; Hult, G.T.M.; Ringle, C.M.; Sarstedt, M. A Primer on Partial Least Squares Structural Equation Modeling (PLS-SEM), 2nd ed.; Sage: Thousand Oaks, CA, USA, 2017.

51. Becker, J.M.; Klein, K.; Wetzels, M. Hierarchical Latent Variable Models in PLS-SEM: Guidelines for Using Reflective-Formative Type Models. Long Range Plan. 2012, 45, 359-394. [CrossRef]

52. Roldán, J.L.; Sánchez-Franco, M.J. Variance-based structural equation modeling: Guidelines for using partial least squares in information systems research. In Research Methodologies in Engineering of Software Systems and Information Systems: Philosophies, Methods and Innovations; Mora, M., Gelman, O., Steenkamp, A., Raisinghani, M., Eds.; Information Science Reference: Hershey, PA, USA, 2012; pp. 193-221.

53. Barroso, C.; Cepeda, G.; Roldán, J.L. Applying maximum likelihood and PLS on different sample sizes: Studies on SERVQUAL model and employee behaviour model. In Handbook of Partial Least Squares; Esposito Vinzi, V., Chin, W., Henseler, J., Wang, H., Eds.; Springer Handbooks of Computational Statistics; Springer: Berlin/Heidelberg, Germany, 2010.

54. Castro, I.; Roldán, J.L. A mediation model between dimensions of social capital. Int. Bus. Rev. 2013, 22, 1034-1050. [CrossRef]

55. Wold, H. Systems analysis by partial least squares. In Measuring the Unmeasurable; Nijkamp, P., Leitner, H., Wrigley, N., Eds.; Martinus Nijhoff Publishers: Dordrecht, The Netherlands, 1985.

56. Chin, W.W. How to write up and report PLS analyses. In Handbook of Partial Least Squares: Concepts, Methods and Applications; Esposito Vinzi, V., Chin, W.W., Henseler, J., Wang, H., Eds.; Springer: Berlin/Heidelberg, Germany, 2010.

57. Segarra-Moliner, J.R.; Moliner-Tena, M.A. Customer equity and CLV in Spanish telecommunication services. J. Bus. Res. 2016, 69, 4694-4705. [CrossRef]

58. Ringle, C.M.; Wende, S.; Becker, J.M. Smart PLS 3.2.6; Computer Software; SmartPLS GmbH: Boenningstedt, Germany, 2018. Available online: http: / / www.smartpls.com (accessed on 22 October 2018).

59. Henseler, J. Adanco 2.0.1. User Manual; Composite Modelling GmbH \& Co.: Kleve, Germany, 2017.

60. Tenenhaus, M.; Esposito, V.; Chatelin, Y.; Lauro, C. PLS path modeling. Comput. Stat. Data Anal. 2005, 48, 159-205. [CrossRef]

61. Carmines, E.G.; Zeller, R.A. Reliability and Validity Assessment; Sage Publications: Thousand Oaks, CA, USA, 1979.

62. Barclay, D.; Higgins, C.; Thompson, R. The Partial Least Squares (PLS) approach to causal modeling, personal computer and use as an illustration (Special Issue on Research Methodology). J. Technol. Stud. 1995, 2, $285-309$.

63. Dijkstra, T.K.; Henseler, J. Consistent partial least squares path modeling. MIS Q. 2015, 39, $297-316$. [CrossRef]

64. Hair, J.F.; Ringle, C.; Sarstedt, M. PLS-SEM: Indeed a silver bullet. J. Mark. Theory Pract. 2011, 19, 139-152. [CrossRef]

65. Henseler, J.; Ringle, C.M.; Sinkovics, R.R. The use of partial least squares path modeling in international marketing. Adv. Int. Mark. 2009, 20, 277-320. 
66. Henseler, J.; Dijkstra, T.K.; Sarstedt, M.; Ringle, C.M.; Diamantopoulos, A.; Straub, D.W. Common beliefs and reality about partial least squares: Comments on Rönkkö \& Evermann (2013). Organ. Res. Methods 2014, 17, 182-209.

67. Hu, L.T.; Bentler, P.M. Fit indices in covariance structure modeling: Sensitivity to underparameterized model misspecification. Psychol. Methods 1998, 3, 424-453. [CrossRef] 